\title{
Analisis Pengaruh Komitmen, Lingkungan Kerja Dan Disiplin Kerja Terhadap Kinerja Pegawai Dinas Kependudukan Dan Catatan Sipil Kabupaten Pasaman Barat
}

\author{
Muhammad Jamil \\ Fakultas Ekonomi Universitas Putra Indonesia YPTK Padang \\ Mjljamil01@gmail.com
}

\begin{abstract}
This study aims to reveal. (1) Analysis of the influence of Commitments on employee performance, (2) Work Environment on employee performance, (3) Work Discipline on employee performance, (4) Analysis of the Effect of Commitment, Work Environment and Work Discipline and simultaneously on Employee Performance. The population of this study were all employees at the Population and Civil Registration Office of West Pasaman Regency, amounting to 58 people. Samples were taken from all populations, namely 58 people. The analysis method uses multiple regression analysis. Research Results obtained 1) Commitment variables, work environment and work discipline simultaneously have a positive and significant effect on the performance of the Civil Registration and Civil Registration Service Office of West Pasaman Regency. The contribution of commitment variables, work environment and work discipline to employee performance is $51.6 \%$, while the remaining $48.4 \%$ is influenced by other variables not included in the scope of this research. 2. Commitment variables, work environment and work discipline partial has a positive and significant effect on the performance of the Civil Servants and Civil Registration Offices of West Pasaman Regency.
\end{abstract}

Keywords: Commitment, Work Environment, Work Discipline and Employee Performance

\section{Pendahuluan}

Sumber Daya Manusia merupakan salah satu bidang strategis yang menjadi perhatian. Organisasi yang mampu bersaing adalah organisasi yang mempunyai sumber daya manusia yang berkualitas dengan berbasis ilmu pengetahuan dan memiliki ketrampilan. Sumber daya manusia dalam organisasi memiliki peranan dan fungsi yang sangat penting bagi tercapainya tujuan organisasi. Sumber daya manusia di sini mencakup keseluruhan manusia yang ada dalam organisasi yaitu mereka yang terlibat dalam kegiatan operasional organisasi, seluruh elemen sumber daya manusia memiliki peran yang sama terhadap tercapai tidaknya tujuan organisasi. Pegawai merupakan sumber daya manusia yang pada dasarnya merupakan bagian dari organisasi, artinya sebagai anggota organisasi, pegawai hendaknya secara efektif ikut serta memajukan organisasi, memberikan nilai tambah pada organisasi dalam setiap aspek sesuai dengan kemampuan dan lingkungan kerjanya. Berhasil tidaknya suatu perusahaan atau organisasi dalam pencapaian tujuan dan target-target operasionalnya tidak lepas dari peran pegawai yang berkompeten dan berintegrasi tinggi. Keberhasilan suatu organisasi sangat tergantung pada sumberdaya manusianya, seberapa bagus program-program yang dibuat, tidak ada artinya tampa sumberdaya yang berkualitas yang mengukir prestasi tinggi dalam setiap pelaksanaan kegiatan dan tugas yang diberikan kepadanya. Untuk memperoleh sumberdaya yang berkualitas tentu dibutuhkan lingkungan kerja yang nyaman dan kondusif, dengan lingkungan kerja yang menyenangkan setiap pegawai dapat bekerja dengan baik dan menyelesaikan tugasnya dengan kinerja yang tinggi. Disamping itu, untuk mencapai tujuan organisasi perlu diupayakan langkah-langkah yang terencana, sistematik, berkelanjutan, dan terkoordinasi dalam meningkatkan kualitas dan pengabdian pegawai. Pada hakikatnya kinerja merupakan hasil kerja yang dicapai oleh seseorang dalam melaksanakan tugasnya sesuai dengan standar dan kriteria yang ditetapkan untuk pekerjaan tersebut. Kinerja merupakan salah satu kumpulan total dari kerja yang ada pada diri 
pekerja atau tugas yang diberikan. Kinerja merupakan suatu fungsi dari motivasi dan kemampuan untuk menyelesaikan tugas dan pekerjaan, seseorang harus memiliki derajat kesediaan dan tingkat kemampuan. Kinerja merujuk pada tingkat keberhasilan dalam melaksanakan tugas serta kemampuan untuk mencapai tujuan yang telah ditetapkan. Jika tujuan yang diinginkan dapat tercapai dengan baik, maka kinerja dinyatakan baik dan sukses. Mangkunegara (2008) menilai kinerja karyawan berkenaan dengan hasil pekerjaan yang dicapai karyawan dalam kurun waktu tertentu yang diukur berdasarkan kuantitas maupun kualitas hasil kerja.

Strategi peningkatan kinerja adalah cara organisasi untuk meningkatkan kinerja karyawan agar tujuan organisasi dapat tercapai. Agar strategi peningkatan kinerja tersebut dapat berhasil maka organisasi perlu mengetahui faktor- fator yang mempengaruhi kinerja pegawai. Kinerja karyawan ditentukan oleh banyak faktor diantaranya Komitmen Organisasional, lingkungan kerja, dan disiplin kerja (Gibson,2009).Faktor-faktor ini menjadi penting karena dapat meningkatkan kinerja pegawai dalam sebuah organisasi.

Komitmen organisasi menurut Mathis dan Jackson (2011) merupakan tingkat kepercayaan dan penerimaan tenaga kerja terhadap tujuan organisasi dan mempunyai keinginan untuk tetap ada di dalam organisasi tersebut, sedangkan Robbins dan Judge (2008) mengemukakan bahwa komitmen organisasi sebagai suatu keadaan dimana seorang individu memihak organisasi serta tujuan-tujuan dan keinginannya untuk mempertahankan keangotaannya dalam organisasi.Senada dengan kedua pendapat tersebut Richard M. Steers (Sri , 2001) juga menyatakan komitmen organisasi sebagai rasa identifikasi (kepercayaan terhadap nilai-nilai organisasi), keterlibatan (kesediaan untuk berusaha sebaik mungkin demi kepentingan organisasi) dan loyalitas (keinginan untuk tetap menjadi anggota organisasi yang bersangkutan) yang dinyatakan oleh seorang pegawai terhadap organisasinya.

Sekarang ini komitmen organisasi dapat dijadikan landasan daya saing (competitive advantages), karena organisasi atau perusahaan dengan karyawan yang komit akan mendapatkan keunggulankeunggulan yang tidak dimiliki oleh organisasi atau perusahaan lain seperti : adanya kepercayaan yang kuat untuk menerima tujuan dan nilai-nilai organisasi, kesediaan untuk melakukan usaha yang diatasnamakan organisasi, serta adanya keinginan yang kuat untuk mempertahankan keanggotaannya di dalam organisasi tersebut (Mathis dan Jackson, 2011). Komitmen organisasi didefinisikan sebagai hasrat yang dimiliki oleh seorang pegawai untuk tetap menjadi anggota suatu organisasi (Dessler, 2009). Komitmen organisasi mempengaruhi sikap atau perilaku pegawai untuk tetap bekerja di suatu organisasi atau meninggalkan organisasi. Oleh sebab itu, komitmen organisasi menjadi isu penting dalam konstelasi perubahan organisasi yang di dalamnya terkait dengan manajemen dan perilaku sumber daya manusia (pegawai). Pada komitmen organisasi terkait dengan rasa identifikasi (kepercayaan terhadap nilai-nilai organisasi), keterlibatan (kesediaan untuk berusaha sebaik mungkin demi kepentingan organisasi) dan loyalitas (keinginan untuk tetap menjadi anggota organisasi yang bersangkutan). Tiga unsur utama dalam komitmen organisasi (rasa identifikasi, keterlibatan dan loyalitas) tersebut menjadi dasar yang sangat penting bagi pegawai untuk mencapai keberhasilan dalam melaksanakan tugasnya, sehingga tercipta kinerja yang baik. Dengan demikian pegawai yang mempunyai komitmen yang tinggi terhadap organisasi, maka akan meningkatkan kinerja pegawai tersebut.

Faktor lain yang mempengaruhi kinerja pegawai adalah lingkungan kerja. Lingkungan kerja (Saydam, 2007) adalah keseluruhan sarana dan prasarana yang ada di sekitar karyawan yang sedang melakukan pekerjaan yang dapat mempengaruhi pelaksanaan pekerjaan itu sendiri. Lingkungan kerja ini akan meliputi tempat kerja. Fasilitas dan alat bantu pekerjaan, kebersihan, pencahaya, ketenangan termasuk juga hubungan kerja antara orang-orang yang ada di tempat tersebut. Lingkungan kerja yang menyenangkan dapat mencakup tempat kerja dan fasilitas-fasilitas bantu yang mempercepat penyelesaian pekerjaan. Setiap karyawan akan mengharapakan lingkungan kerja tempat mereka bekerja baik dan tidak membosankan. Bila lingkungan kerja yang tidak seperti yang diharapkan maka hal ini akan berpengaruh besar terhadap suasana kerja dan kebiasaan kerja karyawan sehingga berdampak langsung terhadap hasil kerja dan kepuasan kerja karyawan yang bersangkutan. 
Disamping itu disiplin bermanfaat mendidik pegawai untuk mematuhi dan menyenangi peraturan, prosedur, maupun kebijakan yang ada, sehingga dapat menghasilkan kinerja yang baik. Faktor kedisiplinan memegang peranan yang amat penting dalam pelaksanaan kerja pegawai. Apabila pegawai bekerja dengan disiplin yang tinggi, dan lingkungan kerja yang kondusif. maka pegawai akan bekerja dengan komitmen yang tinggi dengan menggunakan segenap kemampuan yang mereka miliki sehingga menghasilkan kinerja yang tinggi untuk mencapai tujuan organisasi dimana mereka bekerja, walaupun disadari oleh banyak pihak bahwa komitmen, lingkungan kerja dan disiplin kerja pegawai merupakan faktor penting dalam kinerja pegawai, namun dalam prakteknya belum semua organisasi mampu mewujudkannya. Salah satu contohnya adalah di Dinas Kependudukan Dan Catatan Sipil Kabupaten Pasaman Barat .

Organisasi Dinas Kependudukan dan Catatan Sipil Kabupaten Pasaman Barat berdiri pada tanggal 31 September 2008 beralamat Jln. KKN Kampung Cubadak Simpang Empat Pasaman Barat, dibentuk berdasarkan Peraturan Daerah Nomor 06 Tahun 2008 tentang Pembentukan Organisasi dan Tata Kerja Lembaga Teknis Daerah Kabupaten,berdasarkan Peraturan Daerah tersebut di atas Dinas Kependudukan dan Catatan Sipil Kabupaten Pasaman Barat adalah merupakan unsur pelaksana Pemerintah Daerah di bidang kependudukan dan catatan sipil, dipimpin oleh seorang Kepala Dinas yang berada di bawah dan bertanggungjawab kepada Bupati melalui Sekretaris Daerah.

Berdasarkan Peraturan Daerah Nomor 06 Tahun 2008, tugas pokok Dinas Kependudukan dan Catatan Sipil Kabupaten Pasaman Barat yaitu melaksanakan kewenangan daerah di bidang kependudukan dan catatan sipil yang karena sifatnya tidak tercakup oleh Sekretariat Daerah dan Dinas Daerah Kabupaten Pasaman Barat. Sedangkan fungsi Dinas Kependudukan dan Catatan Sipil adalah :

1. Penyiapan penyusunan peraturan perundang-undangan daerah di bidang kependudukan dan catatan sipil sesuai dengan norma, standard dan prosedur yang ditetapkan pemerintah.

2. Penyiapan kebijakan teknis pengembangan kependudukan dan catatan sipil.

3. Penyiapan dan pelaksanaan program penempatan dan penyusunan data kependudukan.

4. Pelayanan administrasi kependudukan dan catatan sipil sesuai dengan norma, standard dan prosedur yang ditetapkan peraturan perundang-undangan.

Dalam pelaksanaan fungsi nya Dinas Kependudukan dan Catatan Sipil Kabupaten Pasaman Barat membuat program kerja supaya pencapaian tujuan / visi lebih mudah, lebih efektif dan lebih efesien. Program - Dinas Kependudukan dan Catatan Sipil Kabupaten Pasaman Barat adalah 1) Program dan Kegiatan Lokalitas Kewenangan SKPD yang terditi dari a) 1. Pelayanan Administrasi Perkantoran, b) Peningkatan sarana dan prasarana aparatur, c) Peningkatan disiplin aparatur d) Peningkatan Kapasitas Sumber Daya Aparatur,e) Penataan administrasi kependudukan. 2) . Program dan Kegiatan Lintas SKPD, 3 ) program dan Kegiatan Kewilayahan.

Begitu kompleksnya program dari Dinas Kependudukan dan Catatan Sipil Kabupaten Pasaman Barat, maka semua sumberdaya manusia yang berada di Dinas Kependudukan dan Catatan Sipil Kabupaten Pasaman Barat ini harus saling bekerja sama dengan bersungguh- sungguh agar pelaksanaa program kerja berjalan dengan lancar dan dapat melayai masyarakat sesuai dengan standar yang dibuat. Hal ini bisa dicapai apabila seluruh pegawai yang berada dibawah naungan Dinas Kependudukan dan Catatan Sipil Kabupaten Pasaman Barat memiliki kinerja yang tinggi.

Pada Dinas Kependudukan dan Catatan Sipil Kabupaten Pasaman Barat terlihat kinerja pegawai belum menunjukkan kondisi yang optimal. Faktanya antara lain masih adanya keluhan para pegawai dalam menjalankan pekerjaannya, keluhan masyarakat dalam pelayanannya, tidak disiplin dalam bekerja, sering pulang cepat, terlambat masuk kantor, keluar kantor tanpa ada ijin resmi dan memperpanjang jam istirahat. Gejala seperti ini jelas akan mengganggu kinerja pegawai dalam suatu organisasi sehingga perlu dilakukan pembenahan untuk meningkatkan kinerja pegawai. 
Berdasarkan permasalahan dan fenomena tersebut diatas sebagai dasar penulis tertarik untuk melakukan penelitian dengan judul : "Analisis pengaruh Komitmen, lingkungan kerja dan disiplin kerja terhadap kinerja pegawai pada Dinas Kependudukan dan Catatan Sipil Kabupaten Pasaman Barat.

\section{Landasan Tiori}

\subsection{Pengertian Sumber Daya Manusia ( SDM )}

Manajemen sumber daya manusia (MSDM) merupakan salah satu bidang dari manajemen umum yang meliputi segi-segi perencanaan, pengorganisasian, pelaksanaan dan pengendalian. Proses ini terdapat dalam fungsi atau bidang produksi, pemasaran, keuangan maupun kepegawaian. Karena sumber daya manusia (SDM) dianggap semakin penting perannya dalam pencapaian tujuan perusahaan, maka berbagai pengalaman dan hasil penelitian dalam bidang SDM dikumpulkan secara sistematis dalam apa yang disebut manajemen seharusnya memanage (mengelola) sumber daya manusia.Hakikatnya Manajemen Sumber Daya Manusia sangat ditentukan oleh sumber daya itu sendiri, yang selalu berkembang baik jumlah maupun mutunya.

Defenisi Manajemen Sumber Daya Manusia menurut para ahli manajemen :

a) Menurut Rivai (2009) Manajemen SDM merupakan salah satu bidang dari manajemen umum yang meliputi segi-segi perencanaan, pengorganisasian, pelaksanaa, dan pengendalian.

b) Menurut Flippo (Hasibuan 2007) Manajemen Personalia adalah perencanaan, pengorganisasian, pengarahan, dan mengendalikan dari pengadaan, pengembangan, kompensasi, pengintegrasian, pemeliharaan, dan pemberhentian karyawan,dengan maksud terwujudnya tujuan perusahaan, individu, karyawan, dan masyarakat.

c) Menurut Dessler (2009) Manajemen Sumber Daya Manusia adalah kebijakan dan praktek menentukan aspek manusia atau sumber daya manusia dalam posisi manajemen termasuk merekrut, menyaring, melatih, memberi penghargaan, dan penilaian.

d) Menurut Mangkunegara (2008) Manajemen SDM merupakan suatu perencanaan, pengorgansasian, pegkoordinasian, pelaksanaan, dan pengawasan terhadap pengadaan, pemeliharaan, dan pemisahan tenaga kerja, dalam rangka mencapai tujuan organisasi.

\subsubsection{Fungsi Manajemen Sumber Daya Manusia}

Menurut Hasibuan (2007) menjabarkan fungsi-fungsi manajemen sumber daya manusia adalah:

1. Perencanaan

Perencanaan (human resoucer planning) adalah merencanakan tenaga kerja secara efektif dan efisien agar sesuai dengan kebutuhan perusahaan dalam membantu terwujudnya tujuan.

2. Pengorganisasian

Pengorganisasian adalah kegiatan untuk mengorganisasikan semua karyawan dengan menetapkan pembagian kerja, hubungan kerja, delegasi wewenang, integrasi, dan koordinasi dalam bagan organisasi (organization chart). Organisasi hanya merupakan alat untuk mencapai tujuan. Dengan organisasi yang baik akan membantu terwujudnya tujuan secara efektif.

3. Pengarahan

Pengarahan (directing) adalah kegiatan mengarahkan semua karyawan, agar mau bekerja sama dan bekerja secara efektif dalam membantu tercapainya tujuan perusahaan, karyawan dan masyarakat. Pengarahan dilakukan pimpinan dengan menugaskan bawahan agar mengerjakan semua tugasnya dengan baik.

4. Pengendalian 
Pengendalian (controlling) adalah kegiatan mengendalikan semua karyawan. Agar menaati semua peraturan perusahaan dan bekerja sesuai dengan rencana. Apabila terjadi penyimpangan atau kesalahan, diadakan tindakan perbaikan dan penyempurnaan perencanaan. Pengendalian karyawan meliputi kehadiran, kedisiplinan, perilaku kerja sama, pelaksanaan pekerjaan dan menjaga situasi lingkungan pekerjaan

5. Pengadaan

Pengadaan (procurement) adalah proses penarikan, seleksi, penempatan, orientasi dan induksi untuk mendapatkan karyawan yang sesuai dengan kebutuhan perusahaan. Pengadaan yang baik akan membantu terwujudnya tujuan.

6. Pengembangan

Pengembangan (development) adalah proses peningkatan keterampilan tekhnis dan teoritis, konseptual dan moral karyawan melalui pendidikan dan pelatihan. Pendidikan dan pelatihan yang diberikan harus sesuai dengan keburuhan pekerjaan masa kini maupun masa depan.

7. Kompensasi

Kompensasi (kompesation) adalah pemberian balas jasa langsung (direct) dan tidak langsung (indirect), uang atau barang kepada karyawan sebagai imbalan jasa yang diberikan kepada perusahaan.

8. Pengintegrasian

Pengintegrasian (integration) adalah kegiatan untuk mempersatukan kepentingan perusahaan dan kebutuhan karyawan, agar tercipta kerja sama yang serasi dan saling menguntungkan.

9. Pemeliharaan

Pemeliharaan (maintenance) adalah kegiatan untuk memelihara atau untuk meningkatkan kondisi fisik, mental dan loyalitas karyawan, agar mereka mau bekerja sama sampai pensiun.

10. Kedisiplinan

Kedisiplinan merupakan fungsi MSDM yang terpenting dan kunci terwujudnya tujuan karena tanpa disiplin yang baik sulit terwujud tujuan yang maksimal. Disiplin adalah keinginan dan kesadaran untuk mentaati peraturan-peraturan perusahaan dan norma-norma sosial.

11. Pemberhentian

Pemberhentian (separation) adalah putusnya hungan kerja seseorang dari perusahaan. Pemberhentian ini disebabkan oleh keingingan karyawan, keinginan perusahaan, kontrak kerja berakhir, pensiun dan sebab-sebab lainnya.

\subsection{Komitmen}

\subsubsection{Pengertian Komitmen}

Menurut Colquitt et al (2009), "Organizational commitment is defined as the desire on the part of an employee to remain a member of the organization. Organizational commitmen influences whether an employee stays a member of the organization (is retained) or leaves to pursue another job (turns over)" atau dengan kata lain Komitmen organisasi didefinisikan sebagai hasrat yang dimiliki oleh pegawai untuk tetap menjadi anggota organisasi. Komitmen organisasi mempengaruhi seorang pegawai untuk tetap menjadi anggota organisasi atau meninggalkan organisasi untuk mencari pekerjaan di tempat lain.

Komitmen dalam Kamus Besar Bahasa Indonesia (KBBI.2003) diartikan sebagai perjanjian untuk melakukan sesuatu. Nawawi (2007) mengemukakan bahwa komitmen merupakan suatu keputusan atau perjanjian seseorang dengan dirinya sendiri untuk melakukan atau tidak melakukan, berhenti atau meneruskan suatu perbuatan atau kegiatan. Selanjutnya mereka menjelaskan komitmen merupakan penetapan dalam diri seseorang untuk menerima atau menolak satu atau lebih tujuan dan menuntut perbuatan atau kegiatan. Selanjutnya Sahertian (2007) mengemukakan bahwa komitmen merupakan kecenderungan dalam diri seseorang untuk merasa terlibat aktif dengan penuh rasa tanggung jawab. Peran aktif dan penuh rasa tanggung jawab yang dimiliki oleh seorang karyawan administrasi akan mendorong 
terjun langsung dalam suatu kegiatan sehingga sanggup menetapkan keputusan untuk dirinya sendiri dan untuk dilaksanakan sebaliknya.

Arikunto (2006) mengartikan bahwa komitmen bukan sekedar keterlibatan saja, akan tetapi komitmen merupakan suatu kesediaan seseorang untuk terlibat aktif dalam suatu kegiatan dengan tanggung jawab yang tinggi. Secara alamiah semua orang memiliki komitmen. Bedanya, terletak pada tingkat perkembangan dan proses kejiwaan seseorang secara alamiah. Arikunto (2006) juga menyatakan bahwa sikap seseorang berganti, sesuai dengan tingkat perkembangannya. Hal ini bisa dipengaruhi oleh faktor umur. Dengan demikian, sikap seseorang pada waktu muda tidak akan sama setelah lanjut usianya.

Dari pengertian dan uraian tersebut diatas dapat disimpulkan bahwa komitmen adalah suatu kesediaan, keterikatan hati, kepedulian, rasa tanggung jawab, loyalitas, semangat untuk mengembangkan diri, perjanjian pada diri sendiri seseorang untuk mengabdikan diri, terlibat aktif dalam melaksanakan suatu kegiatan atau pekerjaan dengan sungguh-sungguh dan penuh rasa tanggung jawab yang tinggi untuk mencapai tujuan organisasi.

\subsection{Lingkungan Kerja}

\subsubsection{Pengertian Lingkungan Kerja}

Lingkungan kerja adalah segala sesuatu yang ada disekitar para pekerja yang dapat mempengaruhi dirinya dalam menjalankan tugas-tugas yang dibebankan (Nitisemito, 2005). Sedarmayati (2009) mendefinisikan lingkungan kerja adalah keseluruhan alat perkakas dan bahan yang dihadapi, lingkungan sekitarnya di mana seseorang bekerja, metode kerjanya, serta pengaturannya baik sebagai perseorangan maupun sebagai kelompok.

Sedarmayanti (2009) menyatakan bahwa secara garis besar, jenis lingkungan kerja terbagi menjadi 2 yakni : (a) lingkungan kerja fisik, dan (b) lingkungan kerja non fisik. Lingkungan kerja fisik diantaranya adalah: penerangan/cahaya, temperatur/suhu udara, kelembaban, sirkulasi udara, kebisingan, bau tidak sedap, tata warna, dekorasi, musik dan keamanan di tempat kerja. Sedangkan lingkungan kerja non fisik diantaranya adalah hubungan sosial di tempat kerja baik antara atasan dengan bawahan atau hubungan antara bawahan.

Jaya (2005) mengatakan bahwa lingkungan kerja adalah keseluruhan atau setiap aspek dari gejala dan sosial-kultural yang mengelilingi atau mempengaruhi individu. Lingkungan kerja adalah segala sesuatu yang ada di sekitar para pekerja yang dapat mempengaruhi dirinya dalam menjalankan tugas- tugas yang dibebankan, misalnya penerangan, suhu udara, ruang gerak, keamanan, kebersihan, interaksi ssosial pegawai dan lain-lain

Dari beberapa pengertian tersebut dapat ditarik kesimpulan bahwa lingkungan kerja sangat besar pengaruhnya terhadap kebiasaan-kebiasaan karyawan dalam melakukan pekerjaan yang dibebankan kepadanya. Apabila lingkungan kerja yang ada di sekeliling karyawan baik, maka karyawan akan mempunyai disiplin kerja yang tinggi dan otomatis akan terjalin kerjasama yang baik dalam perusahaan sehingga akan mempengaruhi kepuasan kerja karyawan dan pada akhirnya kinerja meningkat. Tetapi apabila lingkungan kerja yang ada di sekeliling karyawan buruk, maka akan menyebabkan rendahnya disiplin kerja sehingga kepuasan kerja akan jadi menurun dan kinerja menurun.

Menurut Nitisemito (2005) pengertian lingkungan kerja adalah segala sesuatu yang ada di lingkungan sekitar para pekerja dan yang dapat mempengaruhi dirinya dalam menjalankan tugas-tugas yang dibebankan kepadanya.

\subsection{Disiplin Kerja.}




\subsubsection{Pengertian Disiplin Kerja}

Pengertian disiplin antara lain dikemukakan oleh Dian R. Newman dan Richard M. Hodgetts (Zainun, 2005) mengatakan bahwa disiplin adalah satu tindakan yang dirancang untuk memperbaiki penyimpangan pegawai dari aturan, prosedur, kebijakan dan norma-norma organisasi. Istilah ini mengandung pengertian hukuman, walau seringkali keadaanya tidak demikian. Beliau membagi disiplin menjadi dua jenis, yaitu :

a. Disiplin Negatif

Disiplin ini digunakan dengan hukuman untuk menjamin kepatuhan terhadap hukum dan aturan organisasi. Yang terbaik mengutarakannya dengan klise "lakukan atau yang lain ". Pendekatan ini masih umum digunakan dalam banyak organisasi dimana pertimbangan mudah mengganti orang yang berhenti dan organisasi tidak memandang perlu pada pegawainya.

b. Disiplin Positif

Disiplin ini menggunakan komunikasi dua arah untuk menyampaikan perubahan-perubahan yang diinginkan dalam perilaku kerja dan memberi bimbingan kepada pegawai dalam mengambil tindakan koreksi. Disiplin positif sering disebut disiplin konstruktif, menciptakan keinginan dari pegawai untuk menerima dan menjalankan peraturan, prosedur, kebijakan dan norma-norma organisasi. Pendekatan ini didasarkan kepada kepercayaan orang mau melakukan kerja baik dan bila mereka membuat kesalahan atau melanggar aturan mungkin karena tidak sengaja atau dikerjakan karena alasan baik.

Menurut Siagian (2007) bahwa Pendisiplinan pegawai adalah suatu bentuk pelatihan yang berusaha m,emperbaiki dan membentuk pengetahuan, sikap dan perilaku pegawai sehingga para pegawai tersebut secara sukarela berusaha bekerja secara kooperatif dengan para pegawai yang lain serta meningkatkan prestasi kerjanya.

Menurut Hasibuan (2007) bahwa disiplin adalah kesadaran dan kesediaan seseorang mentaati semua peraturan organisasi dan norma-norma sosial yang berlaku. Kesadaran adalah sikap seseorang yang secara sukarela mentaati semua peraturan dan sadar akan tugas dan tanggung jawab. Kesediaan adalah suatu sikap, tingkah laku dan perbuatan seseorang yang sesuai dengan peraturan tertulis maupun tidak tertulis. Definisi tersebut diatas dapat diartikan bahwa kesediaan untuk mentaati peraturan terkait dengan normanorma social yang biasanya berhubungan dengan tata kehidupan masyarakat dan kesediaan untuk mentaati peraturan tersebut terkait dengan norma-norma sosial yang biasanya berhubungan dengan tata kehidupan masyarakat dimana organisasi itu berada, sehingga seseorang yang berstatus sebagai suatu anggota organisasi yang berada di masyarakat dimana ia tinggal, secara otomatis wajib mentaati aturan dan norma-norma yang ada dalam masyarakat.

\subsection{Kinerja pegawai}

\subsubsection{Pengertian kinerja pegawai}

Mathis dan Jackson (2011) mengatakan bahwa kinerja pada dasarnya adalah apa yang dilakukan atau tidak dilakukan karyawan. Kinerja karyawan adalah yang mempengaruhi seberapa banyak mereka memberi kontribusi kepada organisasi

Menurut Gunawan (2006) kinerja adalah hasil kerja yang dicapai seseorang dalam melaksanakan tugas yang dibebankan kepadanya. Sedangkan Dharma (2008) menyatakan kinerja adalah sesuatu yang dihasilkan atau produk /jasa yang dihasilkan atau yang diberikan oleh seseorang atau sekelompok orang.".

Handoko (2005) berpendapat bahwa kinerja adalah hasil dari kemampuan pelaksanaan tugas yang dibebankan kepada pelaksana/karyawan, akibat perjanjian konsekuensi karyawan. Definisi yang dikemukakan Handoko tersebut dapat diartikan bahwa kinerja dapat dinilai dari kemampuan 
seseorang/kelompok dalam menyelesaikan tugas yang diberikan kepadanya yang sesuai dengan kesepakatan tugas ketika pegawai tersebut memasuki suatu organisasi kerja.

Sementara itu Sehertian (2007) mengemukakan bahwa kinerja biasanya dikaitkan dengan jabatan tugas yang menyangkut pengetahuan, keterampilan dan ciri khas dari pelaku kerja seseorang. Definisi ini menjelaskan bahwa kinerja berkaitan dengan keadaan potensi yang dimiliki seseorang untuk melakukan pekerjaan, tindakan dan tingkah laku yang ditunjukkan dalam bekerja. Setiap organisasi mengharapkan agar kinerja para anggotanya mengarah kepada pencapaian tujuan yang telah ditetapkan. Harsono (2005) mengemukakan bahwa kinerja adalah setiap gerakan, perbuatan, pelaksanaan, kegiatan, atau tindakan sadar yang diarahkan untuk mencapai suatu tujuan atau target yang hendak dicapai.

Dari analisis dan beberapa pendapat ahli diatas dapat disimpulkan bahwa kinerja pegawai adalah kemampuan yang dimiliki dalam melaksanakan tugas Indikatornya ; (1) Pengetahuan tentang pekerjaan, (2) Cara melaksanakan pekerjaan, (3) Kesanggupan menyelesaikan tugas yang dibebankan. (4) Waktu yang digunakan.

Berdasarkan landasan tiori tersebut diatas dari berbagai faktor atau variabel yang telah dikenali (diidentifikasi) sebagai masalah penting yang merupakan sebagai salah satu sebab timbulnya masalah dapat dilihat pada gambar dibawah ini.

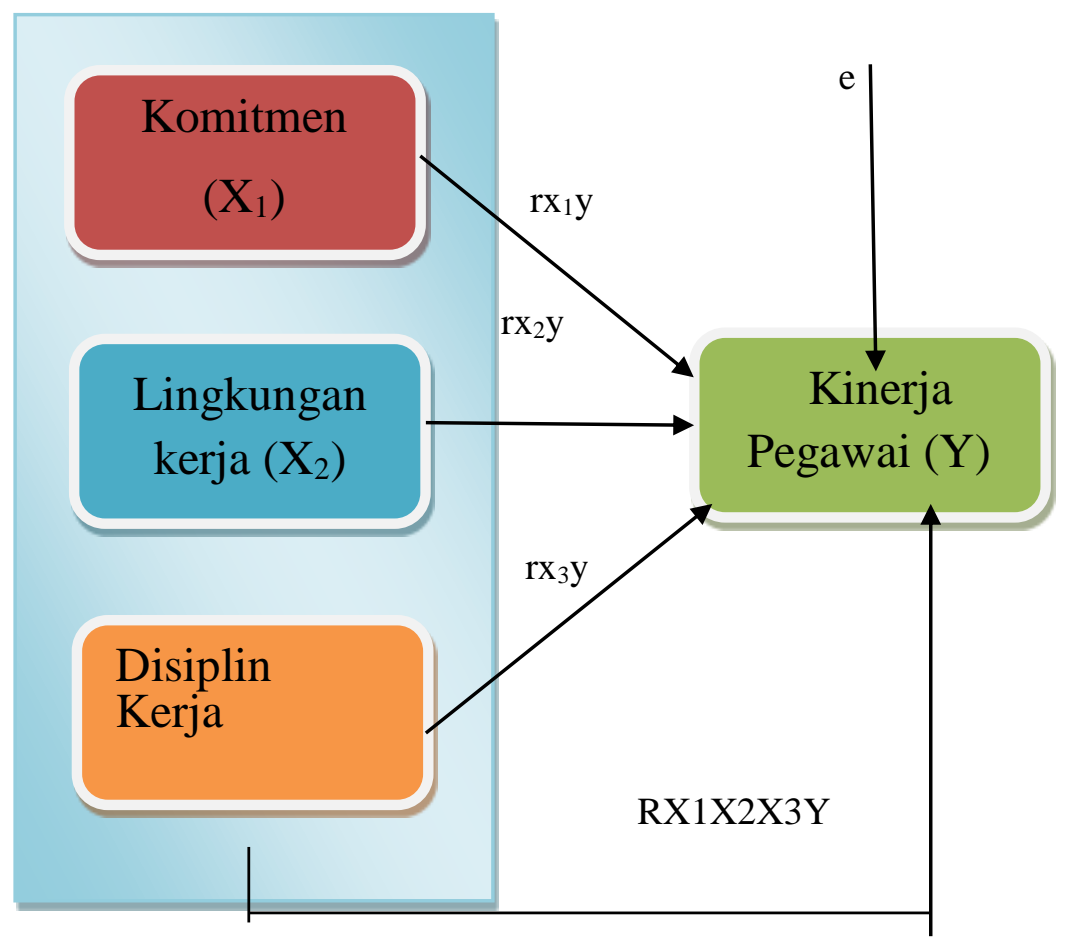

Gambar 2.1 : Kerangka Konseptual 


\section{Metode Penelitian}

Dalam penelitian ini yang digunakan adalah metode survey. Metode Survey menurut Sugiyono (2011) adalah penelitian yang dilakukan pada populasi besar maupun kecil, tetapi data yang dipelajari adalah data dari sampel yang diambil dari populasi tersebut, sehingga dapat ditemukan kejadian-kejadian relatif, distributif dan hubungan antar variabel, sosiologis maupun psikologis. Sedangkan bentuk penelitiannya adalah Penelitian Deskriptif. Penelitian Deskriptif adalah mempelajari masalah masalah deskriptif dalam masyarakat, serta tata cara yang berlaku dalam masyarakat serta situasi-situasi tertentu, termasuk tentang hubungan kegiatan-kegiatan, sikap-sikap, pandangan, serta proses-proses yang sedang berlangsung dan pengaruh-pengaruh dari fenomena.

Penelitian deskritif dilakukan dengan menggunakan teknik korelasi. Teknik ini dilakukan untuk menganalisa hubungan antara tiga variabel bebas yakni komitmen $\left(\mathrm{X}_{1}\right)$ lingkungan kerja $\left(\mathrm{X}_{2}\right)$ dan disiplin kerja $\left(\mathrm{X}_{3}\right)$ dan satu variabel terikat yaitu kinerja pegawai.

\section{Teknik Analisis Data}

Adapun teknik analisa data yang digunakan dalam penelitian ini terdiri dari uji validitas dan reliabilitas, statistik deskriptif, uji koefisien korelasi, uji asumsi klasik, dan uji regresi linear berganda.

\section{Hasil Penelitian dan Pembahasan}

Untuk menganalisis variabel Komitmen, Lingkungan kerja Dan displin kerja dan bagaimana pengaruhnya terhadap Kinerja pegawai, maka dilakukan pengumpulan data dengan menggunakan bantuan kuisioner penelitian. Dalam menyusun kuisioner dibuat daftar pertanyaan, dan setiap pertanyaan telah dilengkapi dengan pilihan jawaban yang harus dipilih oleh responden.

Kuesioner disebarkan kepada 58 responden pegawai Pada Dinas Kependudukan Dan Catatan Sipil Kabupaten Pasaman Barat. Dari proses penyebaran 58 kuisioner seluruhnya berhasil dikumpulkan kembali. Berdasarkan proses pentabulasian data hasil penyebaran kuisioner maka dapat dianalisis dalam penelitian ini.

\section{Pengaruh Komitmen, Lingkungan kerja dan Disiplin kerja terhadap kinerja Pegawai.}

Hasil penelitian menemukan bahwa secara bersama-sama terdapat pengaruh yang positif dan signifikan antara komitmen, lingkungan kerja dan disiplin kerja terhadap kinerja pegawai Dinas Kependudukan Dan Catatan Sipil Kabupaten Pasaman Barat artinya, semakin tinggi lingkungan kerja. Komitmen dan disiplin kerja pegawai, maka akan semakin tinggi pula kinerja pegawai.Sumbangan secara bersama-sama antara variabel komitmen,lingkungan kerja dan disiplin kerja terhadap kinerja pegawai sebesar 51,6\%, dan 48,4\% lainnya dipengaruhi oleh variabel lain yang tidak diteliti seperti iklim organisasi , supervisi, pelatihan pegawai, pengembangan karier, budaya organisasi, lingkungan kerja, motivasi, gaya kepemimpinan, motivasi, kompensasi dan lain-lainnya.

\section{Pengaruh Komitmen dan Kinerja Pegawai}

Berdasarkan hasil pengujian hipotesis kedua, diketahui bahwa komitmen berpengaruh signifikan terhadap kinerja Dinas Kependudukan Dan Catatan Sipil Kabupaten Pasaman Barat. Koefisien regresi 
0,273 bertanda positif menunjukkan terjadinya pengaruh yang searah dari komitmen kepada kinerja pegawai. Hal ini bermakna bila komitmen dapat lebih ditingkatkan dimasa yang akan datang maka akan dapat meningkatkan kinerja pegawai di lingkungan Dinas Kependudukan Dan Catatan Sipil Kabupaten Pasaman Barat. Dengan kata lain, semakin baik dan tinggi komitmen pegawai, maka akan semakin tinggi pula kinerja pegawai Dinas Kependudukan Dan Catatan Sipil Kabupaten Pasaman Barat.

\section{Pengaruh Lingkungan kerja Terhadap Kinerja Pegawai}

Berdasarkan hasil pengujian hipotesis ke II, diketahui bahwa lingkungan kerja berpengaruh signifikan terhadap kinerja pegawai Dinas Kependudukan Dan Catatan Sipil Kabupaten Pasaman Barat. Koefisien regresi 0,289 bertanda positif menunjukkan terjadinya hubungan yang searah dari lingkungan kerja kepada kinerja pegawai. Hal ini bermakna bila lingkungan kerja ditingkatkan dimasa yang akan datang maka akan dapat meningkatkan kinerja pegawai di lingkungan Dinas Kependudukan Dan Catatan Sipil Kabupaten Pasaman Barat . Dengan kata lain, semakin baik lingkungan kerja pegawai, baik lingkungan fisik maupunlingkungan soasial pegawai maka akan semakin tinggi pula kinerja yang dihasilkan pegawai pada Dinas Kependudukan Dan Catatan Sipil Kabupaten Pasaman Barat

\section{Pengaruh Disiplin kerja terhadap Kinerja Pegawai}

Berdasarkan hasil pengujian hipotesis ke II, diketahui bahwa disiplin kerja berpengaruh signifikan terhadap kinerja pegawai pada Dinas Kependudukan Dan Catatan Sipil Kabupaten Pasaman Barat. Koefisien regresi bertanda positif 0,292 menunjukkan terjadinya pengaruh yang searah dari variabel disiplin kerja kepada kinerja pegawai. Hal ini bermakna bila disiplin kerja pegawai ditingkatkan dimasa yang akan datang maka akan dapat meningkatkan kinerja pegawai dan semakin tinggi disiplin kerja pegawai, maka akan semakin tinggi kinerja yang dihasilkan pegawai pada Dinas Kependudukan Dan Catatan Sipil Kabupaten Pasaman Barat Disiplin kerja sebagaimana dikemukakan oleh Nitisemito (2005), kedisiplinan diartikan sebagai suatu sikap, tingkah laku atau perbuatan yang sesuai dengan peraturan, baik yang bersifat tertulis maupun peraturan yang tidak tertulis. Disamping itu ada pendapat dari syarif ( dalam Handoko, 2006), disiplin pada hakekatnya adalah suatu ketaatan yang sungguhsungguh yang didukung oleh kesadaran untuk menunaikan tugas, kewajiban serta berperilaku sebagaimana mestinya menurut aturan atau tata kelakuan yang berlaku dalam suatu lingkungan tertentu. Jadi semakin taat pegawai terhadap peraturan-peraturan yang ditetapkan baik tertulis maupun tidak tertulis maka semakin tinggi kinerja yang dihasilkan pegawai.

\section{KESIMPULAN DAN SARAN 1.1. Kesimpulan}

Berdasarkan analisa data, interpretasi hasil penelitian, dan pembahasan yang telah disampaikan sebelumnya, maka dapat dikemukakan beberapa kesimpulan dari hasil penelitian ini sebagai berikut:

1. Variabel komitmen, lingkungan kerja dan disiplin kerja secara serentak berpengaruh positif dan signifikan terhadap kinerja Dinas Kependudukan Dan Catatan Sipil Kabupaten Pasaman Barat. Sumbangan pengaruh variabel komitmen, lingkungan kerja dan disiplin kerja terhadap kinerja pegawai sebesar 51,6\%, sedangkan sisanya sebesar 48,4\% dipengaruhi oleh variabel lain yang tidak termasuk kedalam ruang lingkup penelitian ini .

2. Variabel komitmen, lingkungan kerja dan disiplin kerja secara parsial berpengaruh positif dan signifikan terhadap kinerja pegawai Dinas Kependudukan Dan Catatan Sipil Kabupaten Pasaman Barat. 


\section{DAFTAR PUSTAKA}

1) Arikunto, Suharsim 2003. Metode Penelitian: Suatu Pendekatan Praktek. Jakarta: Rineka Cipta.

2) Dessler, G. 2009. Human Resource Management. 8th edition. New Jersey: Prentice-Hall,Inc.

3) Gouzali, Saydam. 2007. Manajemen Sumber Daya Manusia (Cetakan V) Yogyakarta: CV Andi Offset

4) Gunawan, 2006. Manajemen Personalia, Jakarta : Bumi Aksara.

5) Gibson, Ivancevich, Donnely, 2009. Organizations (Terjemahan), Cetakan Keempat, PT. Gelora Aksara Pratama, Jakarta.

6) Handoko, T. Tani. 20007Manajemen Personalia dan Sumber Daya Manusia. BPEE. Yokyakarta.

7) Hasibuan, SP Malayu (2007). Manajemen Sumber Daya Manusia; Dasar dan Kunci Keberhasilan. Jakarta : Mas Agung.

8) Harsono. (2005), Manajemen Sumber Daya Manusia. Yogyakarta: Unit Penerbitan Fakultas Ekonomi - UMY.

9) Mathis, Robert L and Jackson, John H, 2011, Manajemen Sumber Daya Manusia, Edisi 10,terjemahan, Salemba Empat

10) Mangkunegara, Anwar Prabu (2008) Manajemen sumber daya manusia, Bandung. Remaja. Rosda karya.

11) Siagian, S.P., 2007, Manajemen Sumber Daya Manusia, PT. Bumi Aksara, Jakarta.

12) Suhertian, 2005. Manajemen Sumber Daya Manusia, BPFE : Yogyakarta.

13) Sedarmayanti, (2007) Manajemen Sumber Daya Manusia (Reformasi Birokrasidan Manajemen Pegawai Negri Sipil), Bandung: PT. Refika Aditama.

14) Robbins, Stephen P., (2002), Organization Behavior:Concept, Concensus and Application, Prentice Hall Inc.

15) Dharma, Surya. (2008). Manajemen Prestasi Kerja: Yogyakarta: Rajawali

16) Gusman, A. P., \& Kurniawan, H. (2018). FUZZY LOGIC DALAM MENGANALISA PENGARUH KONSEP HALAL TOURISM TERHADAP PERILAKU MASYARAKAT SUMATERA BARAT. Jurnal Matematika UNAND, 7(2). 